\title{
On the Establishment of Feng Shui Villages from the Perspective of Old Fukugi Trees in Okinawa, Japan
}

\author{
Bixia Chen and Yuei Nakama
}

\begin{abstract}
A Feng Shui village landscape features Fukugi (Garcinia subelliptica) tree lines surrounding every house and orderly laid out roads. Such a green landscape, which is assumed to be planned or reformed during the modern Ryukyuan period around 300 years ago, is well preserved in Okinawa Island, Japan, and its nearby isolated islands. But it is still a mystery to the historians when and how these Fukugi trees were planted. In order to clarify the development process of the house-embracing Fukugi trees, all Fukugi trees that were assumed to be older than 100 years in Bise, Tonaki, Imadomari, and Aguni Island were measured. It was found that huge Fukugi trees older than 200 years, cluster around the core area kami-asagi or haisyo inside the village. Both the kami-asagi and haisyo are sacred places where guardian gods were summoned in order to hold ceremonies and rituals. The oldest trees were approximately 300, 268, 294, 296, and 281 years in Bise, Tonaki, Imadomari, Yae (East \& West), and Hama in Aguni Island, respectively. These old trees might have been planted prior to the period from 1737 to 1750, when Sai On was a member of the Sanshikan, during which Fukugi trees were planned and recommended. While Fukugi trees might have been planted as windbreaks around the houses prior to the Sai On period, however, the current house-embracing Fukugi tree landscape came into being during the Sai On period based on Feng Shui concepts. Key Words: Feng Shui Village; Fukugi; Garcinia subelliptica; Isolated Islands; Old Trees; Sacred Sites.
\end{abstract}

Feng Shui practice is based on empirical observation of the surrounding landform. Its ultimate goal is to achieve harmony between man and nature. Feng Shui originated in mainland China and then expanded to other regions in East Asia. Feng Shui was first introduced to the Ryukyu Kingdom (Figure 1) in Okinawa at the end of the 14th Century with the earliest Chinese immigrants. Historical literature related to Feng Shui villages in Okinawa is very limited. However, a complete record of Feng Shui village inspections over a period of 30 years, from 1857 to 1888 , exists in the old Haneji District of mainland Okinawa (Ono 2006). Tree planting has been highlighted in these Feng Shui diaries. Dense forests were required to be planted on the Feng Shui sites which are tightly linked to the Feng Shui of the entire village. Fukugi (Garcinia subelliptica Merr.) tree lines were planted to surround the entire hamlet, called Village Ho:go, and even every house (Chen and Nakama 2011). A brief record of village Feng Shui inspection in the Yaeyama Islands in the south of Okinawa Prefecture by a Feng Shui master named Tei Ryosa (C. Zheng Liangzuo), from 1863 to 1864, was titled Hokubokusan Feng Shui Diary (1864). A hand written copy of Hokubokusan Feng Shui Diary by Hanayama Soni (花山孫位) was found in 1965 (Machida and Tsuzuki 1993). From these limited records, it is evident that Feng Shui masters assisted in the settlement of a new village and the improvement of village landscapes. These Feng Shui villages are located on small islands or sandy land close to the coast. Houses are clustered and laid out mostly in orderly fashion, with Fukugi tree lines surrounding each house. Tree lines were also called yashiki ho:go. Ho:go is a Feng Shui term, literally meaning to embrace and protect. Trees are laid out in a line around the house to protect it from strong typhoons in summer, and monsoon winds in winter. In his famous work concerning

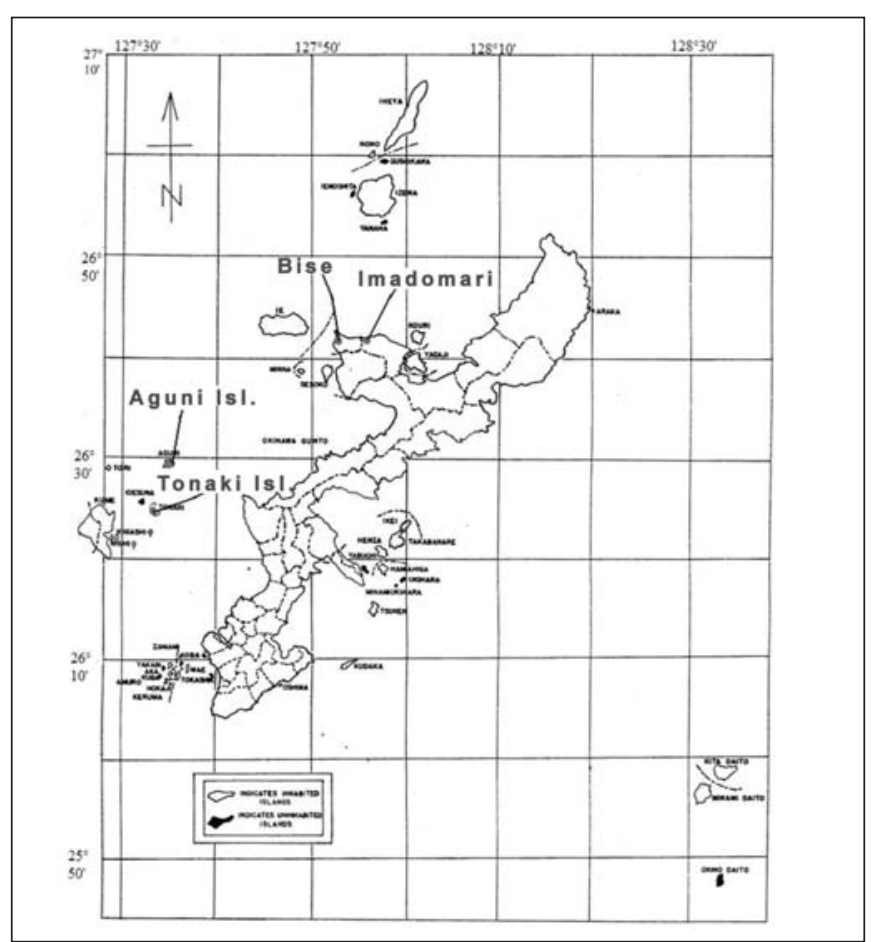

Map of Ryukyu Islands and survey sites. Source: Ryukyu Islands (1953) by United States Civil Administration. 
forestation techniques, Sanrin Shinpi (山林真秘), Sai On emphasizes the importance of close embracing mountains (ho:go) for growing good timber and suggests tree planting to compensate for the low topography in the surroundings (Purves et al. 2009).

In a typical Feng Shui village, the natural forest behind the village and planted forest belt at the front have been preserved and rich biodiversity is found in such forests (Chen 2008; Chen et. al 2008a). Sacred forests preserved by the local people, although in fragmented patches and only in small areas, were also reported in and outside Asia (Zhuang and Gorlett 1997; Ramanujam et. al 2003; Upadhaya et. al 2003; Mgumia and Oba 2003). With economic development and rapid urbanization, forests are disappearing. Even the culturally conserved forests are vanishing as a result of commercial agriculture (Chandrakanth et. al 2004).

House-embracing Fukugi trees have been prevalent in the islands of Okinawa Prefecture (Shigematsu 1979). The oldest trees might have been planted around 300 years ago (Chen and Nakama 2010). A Feng Shui village landscape featuring tree lines is worthy of further study as a sustainable and ecological landscape.

House-embracing Fukugi trees might have been recommended by the then Kingdom of Ryukyu. Fukugi trees are a slow growing species that have played an important role in farmers' lives as windbreaks, firewood, and even green fertilizer. In terms of the features of Fukugi trees, please refer to previous research (Shigematsu 1979; Chen et al. 2008b).

House-embracing Fukugi trees were functionally laid out with denser forests on the northern side of the houses and on the sides facing the sea (Chen et. al 2005; Chen et al. 2006; Chen et al. 2008b; Ando and Ono 2008).

Forests planted hundreds of years ago for cultural purposes are disappearing due to economic and social changes. Such green Feng Shui village landscapes have been vanishing over past decades as the result of local people rebuilding their houses in concrete (Shigematsu 1979). Immediately following World War II, when the island was badly short of timber, local people cut down mature trees to build houses. War-caused fires during WWII also contributed to the disappearance of Fukugi tree lines inside villages.

Regardless of this steady decline, there exist several well preserved Fuguki tree landscapes in Bise, Imadomari, and Inamine in the northern part of mainland Okinawa, and on the small isolated islands of Tonaki and Aguni.

A case study in Bise village found that tree density in the coastal line and northern side of village was higher than the tree lines inside the village (Chen et al. 2006; Anto and Ono 2008). The authors studied the current layout and density of house-embracing Fukugi trees (Chen et al. 2008a; Chen and Nakama 2010) and the vegetation composition in the village ho:go and the preserved natural forest behind the village (Chen et al. 2008b). In previous studies, all Fukugi trees surrounding several houses in Tonaki, Bise and Aguni Island were surveyed. Fukugi woodlands were higher in density and smaller in Tonaki and Bise than in Aguni (Chen and Nakama 2010).

Being limited in extant historical records, it is a mystery for historians exactly when and by whom such Feng Shui villages were built, and how the village was developed and laid out in Okinawa. In this study, all houses at several locations in Bise and Imadomari in mainland Okinawa, and at Tonaki Island and Aguni Island were surveyed, focusing on the distribution of the remnant large trees in the hope of unveiling the history of the village's establishment through the use of these large trees. By measuring all the large Fukugi trees inside the villages, the spatial distribution of Fukugi trees will be assessed with the aim of recovering how natural and cultural factors relate to the distribution.

Previous case studies of Bise (Chen et. al 2006; Ando and Ono 2008), Tonaki (Chen et. al 2005) and Aguni (Chen and Nakama 2010) discuss the density of Fukugi trees surrounding houses. In this study, large trees were surveyed and included several survey sites.

\section{METHOD AND SURVEY SITES}

The old Fukugi trees inside Feng Shui villages surveyed were measured to understand the development process of village houses. All Fukugi trees whose DBH's (Diameter at Breast Height) were larger than $25 \mathrm{~cm}$ were measured. The heights of old trees were also measured. The estimated tree age was calculated based on the formula [Age (year) $=\mathrm{DBH}(\mathrm{cm}) \div 2 \times 8$ ] by Hirata (2006). At present, Hirata's formula is the only one available to estimate the age of Fukugi trees. Hirata Formula is the only one available at present; however, it has some limitations. First, it was calculated based on the two cut stumps in the southern part of Okinawa Island. Second, other factors such as local site, climatic conditions and competition from other trees besides tree age also affect the annual ring width. Thus, the tree age values calculated from this formula to be used in this paper are approximations, not exact ones. To account for the possible deviation between estimated tree age and the real tree age, a class of 50 years of estimated tree ages is used for the analysis in this paper.

All surveyed house-embracing Fukugi trees were further categorized into four groups ( $\geq 250$ years; 200-249 years; 150-199 years; 100-149 years), based on their estimated ages. A map was reproduced with reference to a residential map published by Zenrin, which is a large company that mainly produces and sells residential maps in Japan. The map was used to present the distribution of Fukugi trees older than 100 years. The four groups of surveyed trees were mapped by house and presented in different colors.

All large trees were measured in Bise, Tonaki Island, Aguni Island, and Imadomari in Nakijin Village. There is only one hamlet in Bise, Tonaki Island, and Imadomari. Imadomari is the result of a merging of the two previous hamlets of Nakijin and Oyatomari. Historically, these two hamlets have merged and separated several times. Since Nakijin and Oyatomari were separated only by a main street, Imadomari is considered as one hamlet in this study from the perspective of the village landscape. There are currently three hamlets on Aguni Island: East, West and Hama. East and West are two adjoining hamlets and were not separated until 1872 (Aguni Son Shi 1984), thus, they are also considered as one village landscape. East and West were named Yae, also called agi (meaning "inland") in contrast to hama (meaning "seashore"). Thus, large trees in the survey sites were grouped into Bise, Tonaki, Imadomari, Yae (East \& West), and Hama. Yae, although an old name, will be used in the following text for the convenience of data analysis.

Residences in Tonaki Island are clustered together in the small narrow sandy plain between two high hills in the north and south, respectively. Tonaki had a population of 502 in 2003. Bise village is an arc-like protruding area on the tip of the Motobu Peninsula facing the ocean to the west. The population was 572 in 2006. Aguni is triangular, with a total area of $7.64 \mathrm{~km}^{2}$. Ryukyu limestone, which is coral limestone formed during the Pleistocene era, extends mainly through the central 
part and the southern end of the island, forming terraces. The two clustered hamlets of East and West villages are located in the center of the island, with the hamlet of Hama near the coast. As of November 2007, the village had a population of 874. Imadomari, covered with sandy soil, is located in the westernmost part of Nakijin Village facing the ocean to the north. Large ports were also located east and west of the hamlet.

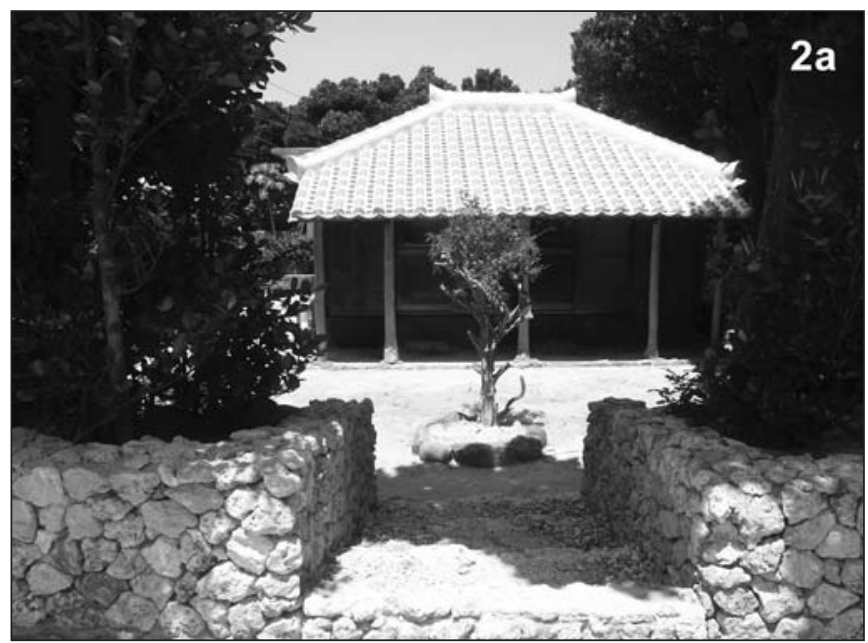

Figure 2. Photos of Fukugi trees in the surveyed sites. 2a) A rebuilt, traditional timber house embraced by Fukugi woods (Tonaki Island).

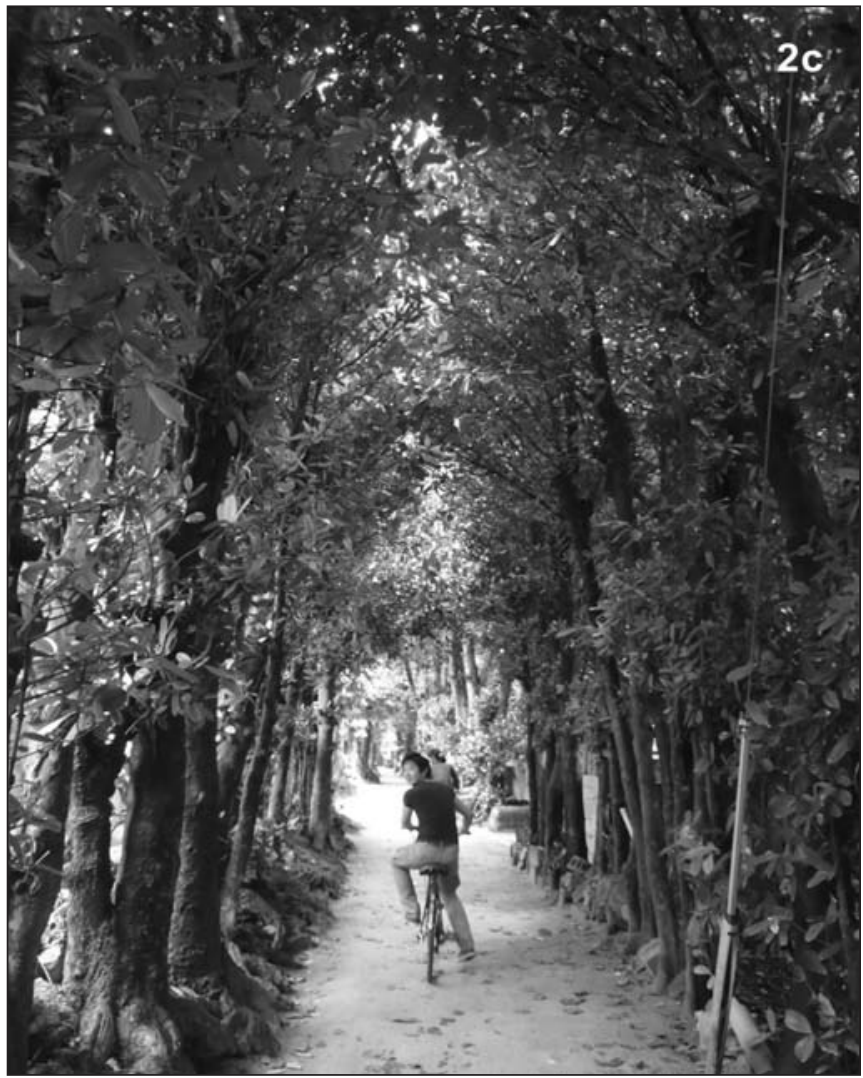

Figure 2c. The old narrow road with the overlapping tree branches at the top (Bise village).

\section{RESULTS AND DISCUSSION}

\section{Distribution of Large Fukugi Trees}

All house-embracing Fukugi trees older than 100 years were measured. It was found that Yae had the highest number of large trees, totaling about 2,500, while Hama, also on Aguni Island,

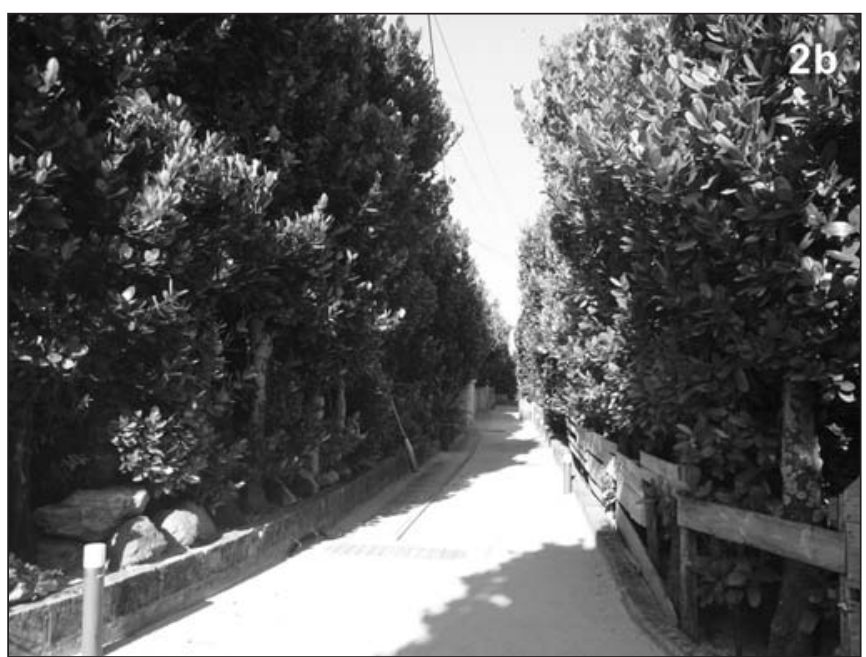

Figure 2b. House-embracing Fukugi trees line the village road covered by white sand (Tonaki Island).

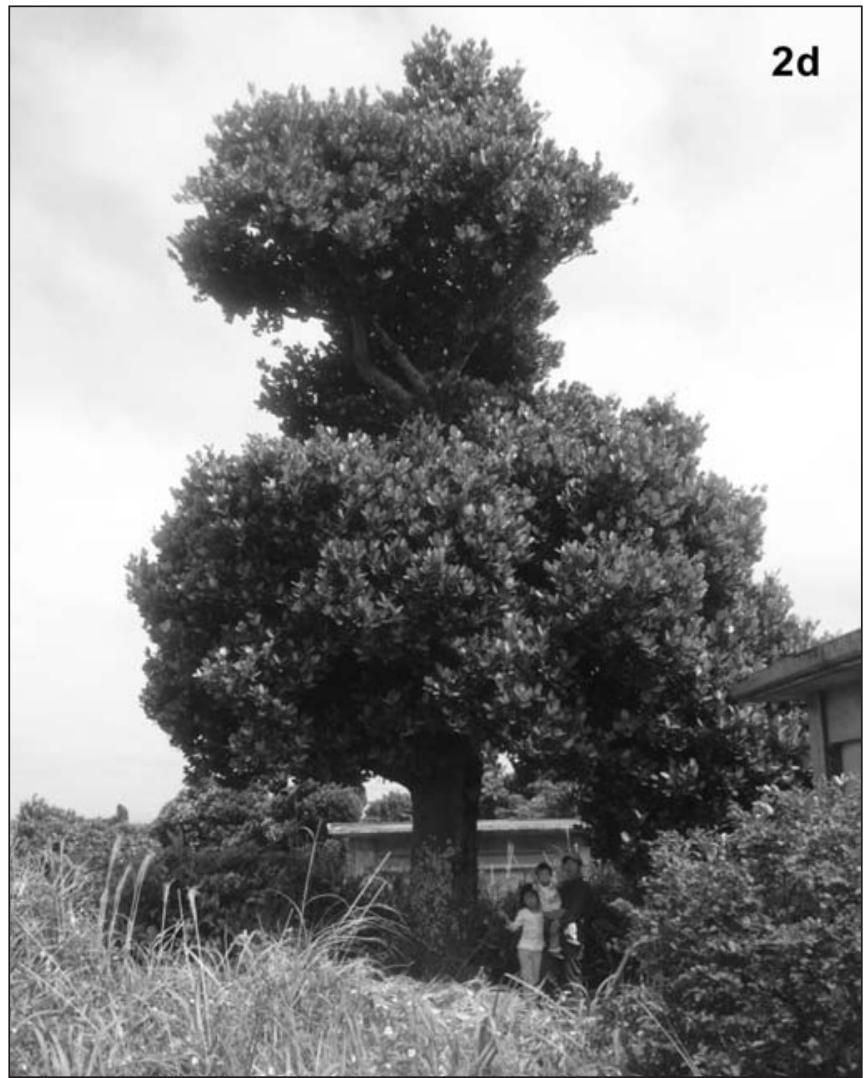

Figure 2d. A huge tree (DBH: $643 \mathrm{~cm}$; TH: $10 \mathrm{~m}$ ) by a vacant house (Aguni Island). 


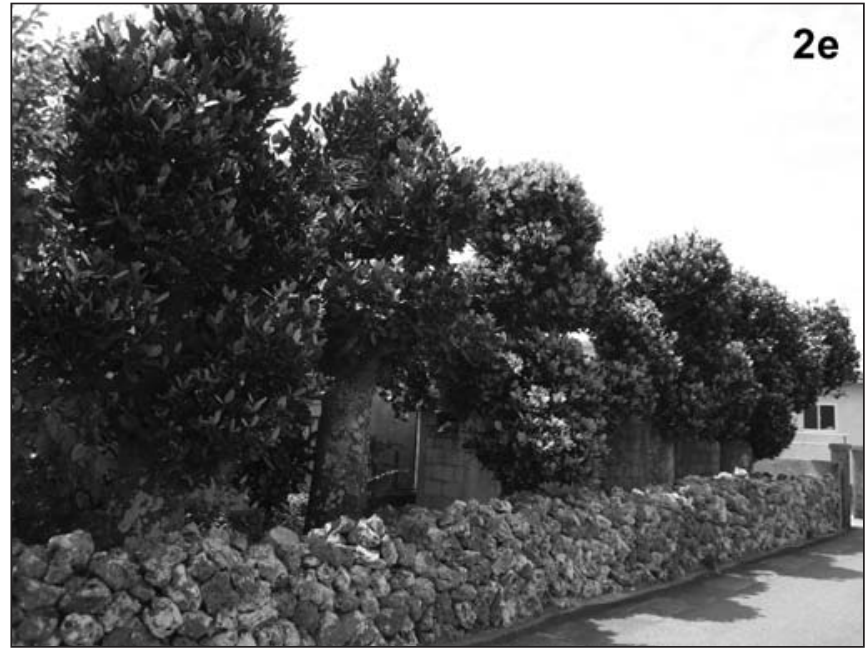

Figure 2e. A huge tree line with the traditional stone fence of coral reef, which were moved inside for the spreading roads. The stone fence was around $1 \mathrm{~m}$ away from the tree line.

had the fewest, totaling about 500 trees (Table 1). Yae has more Fukugi trees in excess of 100 years old than the other three survey sites, and five times as many as in Hama. About 333 houses in Yae were found to have Fukugi trees older than 100 years, but only 85 houses in Hama. According to statistical data from Aguni Village (Anguni Village Stat 2009), in March 2003, the number of registered households and the population were 302 and 615, respectively, in Yae, and 131 and 298 in Hama. The fact that the surveyed house number is larger than the registered household number in Yae suggests many houses lay vacant. The field surveys also found that Fukugi trees have been better preserved in proximity to vacant houses which were always the older houses and used for family rituals, particularly on Aguni Island. Vacant houses also include abandoned houses whose owners have moved out, leaving the premises without manage- ment. In many cases, old houses fell down but the grounds are still used as farm land. Only the still-standing Fukugi trees indicate that a family once lived there. The inhabitants left the house but the trees remain untouched around the premises. In contrast, people moved to more convenient places (e.g., Hama), and replaced old style thatch-roof houses with concrete houses.

Table 1 shows that Bise, Imadomari, and Yae have a larger number of large trees in excess of 200 years old than the other two sites, Tonaki and Hama. The former three sites have a similar number of Fukugi trees older than 200 years, totaling about 100. In contrast, Hama and Tonaki only have about 10 remaining trees older than 200 years.

The oldest trees were approximately 300, 268, 294, 296, and 281 years in Bise, Tonaki, Imadomari, Yae, and Hama, respectively (Table 1). The biggest trees found in Bise and Imadomari in the north of Okinawa were larger than those on small isolated islands. This suggests that Fukugi trees might have been promoted in an earlier age in mainland Okinawa.

The mean tree heights of old Fukugi trees were 994, 842, 900, 723, and $713 \mathrm{~cm}$ in Bise, Tonaki, Imadomari, Yae, and Hama, respectively (Table 1). The fact that Fukugi trees in Bise, Imadomari, and Yae were found to be bigger and taller can be attributed to the local inhabitants' consciousness of the cultural importance of tree conservation. A survey in Bise village by Nakama and Koki (2002) found that about $94 \%$ of the surveyed villagers wanted to preserve house-embracing Fukugi trees. More than $70 \%$ of the surveyed villagers had high regard for Fukugi trees since they protect the houses from typhoons; provide them with shade, and make up a pleasant landscape.

The oldest trees were in the southern part of Bise, in the southeast of Imadomari, and in Yae, Aguni Island. The biggest trees were in the eastern part of Tonaki Island, which is the narrower part of the flat area between two high mountains. Hama is much nearer to the ocean than Yae in Aguni (Chen and Nakama 2010).

According to the renowned statesman and also a Feng Shui master, Sai On, close surroundings are needed to achieve the

Table 1. The Number of remnant Fukugi trees in selected villages.

\begin{tabular}{|c|c|c|c|c|c|c|c|c|c|}
\hline & \multirow{2}{*}{$\begin{array}{l}\text { Area of Village } \\
\text { Houses }\left(\mathrm{m}^{2}\right)^{\mathrm{z}}\end{array}$} & \multicolumn{6}{|c|}{ Number of Remnant Fukugi Trees } & \multirow{2}{*}{$\begin{array}{l}\text { Estimated } \\
\text { age of } \\
\text { biggest tree }\end{array}$} & \multirow{2}{*}{$\begin{array}{l}\text { Mean tree } \\
\text { height }(\mathrm{cm})\end{array}$} \\
\hline & & Total & $\geq 300$ yrs & $250-299$ yrs & $200-249$ yrs & $150-199$ yrs & $100-149$ yrs & & \\
\hline Bise & 191,143 & 1,075 & 1 & 17 & 89 & 360 & 609 & 300 & $994^{y}$ \\
\hline Tonaki & 134,723 & 964 & 0 & 2 & 9 & 111 & 842 & 268 & $842^{y}$ \\
\hline Imadomari & 263,378 & 1,293 & 0 & 15 & 85 & 307 & 886 & 294 & 900 \\
\hline Yae (East \& West) & 384,254 & 2,561 & 0 & 16 & 82 & 486 & 1,977 & 296 & 723 \\
\hline Hama & 137,602 & 541 & 0 & 3 & 6 & 65 & 467 & 281 & 713 \\
\hline
\end{tabular}

${ }^{\mathrm{z}}$ The areas of all village houses is a rough value, calculated based on the residential map published by ZENRIN. The area only includes the houses that were assumed to have been built approximately 100 years ago.

${ }^{y}$ Mean tree heights in Bise and Tonaki was derived from the survey data from 2005-2008.

Table 2. Distribution of Fukugi trees around the house courtyard.

\begin{tabular}{|c|c|c|c|c|c|c|c|c|c|c|}
\hline & \multirow{2}{*}{$\begin{array}{l}\text { Surveyed } \\
\text { house number }\end{array}$} & \multirow{2}{*}{$\begin{array}{l}\text { Total number of } \\
\text { Fukugi } \geq 25 \mathrm{~cm}(\mathrm{dbh})\end{array}$} & \multicolumn{2}{|c|}{ Fukugi in the east $\mathrm{t}^{\mathrm{z}}$} & \multicolumn{2}{|c|}{ Fukugi in the west } & \multicolumn{2}{|c|}{ Fukugi in the south } & \multicolumn{2}{|c|}{ Fukugi in the north } \\
\hline & & & Tree Number & $\%^{y}$ & Tree Number & $\%$ & Tree Number & $\%$ & Tree Number & $\%$ \\
\hline Bise $^{x}$ & 99 & 1075 & - & - & - & - & - & - & - & - \\
\hline Tonaki & 165 & 918 & 276 & 30.1 & 157 & 17.1 & 174 & 19.0 & 311 & 33.9 \\
\hline Imadomari & 155 & 1293 & 299 & 23.1 & 323 & 25.0 & 278 & 21.5 & 393 & 30.4 \\
\hline Yae (East \& West) & 333 & 2561 & 714 & 27.9 & 294 & 11.5 & 357 & 13.9 & 1148 & 44.8 \\
\hline Hama & 85 & 541 & 184 & 34.0 & 59 & 10.9 & 85 & 15.7 & 213 & 39.4 \\
\hline
\end{tabular}

${ }^{\mathrm{z}}$ The trees were classified according to their location relative to the house courtyard.

${ }^{y}$ Refers to the proportion of trees found in one direction in relation to the total surveyed Fukugi trees inside the village.

${ }^{x}$ Bise was surveyed with the help of students in the lab in the summer of 2008 . The tree stand by the side was not recorded. 
harmony of Yin and Yang (Purves et al. 2009). Typical houseembracing Fukugi trees should be positioned in the four directions of the courtyard to create proper protection. However, with the felling of Fukugi trees, such a typical shape is difficult to find inside villages. When the orientation of the remaining trees were averaged, it was found that the greatest number of large Fukugi trees stand to the north of the house, followed by the eastern side, and then southern side (Table 2). The western side has the smallest number of large Fukugi trees. This is in accordance with the fact that monsoonal winds from the north and typhoons from the eastern side are the greatest threat to property. The survey results confirmed assumptions that Fukugi tree layout is strongly correlated with wind direction. Local people have purposely kept the large trees untouched in the northern and the eastern sides of the courtyard.

\section{Huge Trees and the Hamlet Landscape Layout}

Fukugi tree distribution by tree age is shown in Figure 3. It is clear that Fukugi trees older than 100 years are prevalent in Bise, Tonaki, Imadomari, and Yae, while there are few in Hama. From Figure 3, shows a tendency for huge trees older than 200 years to cluster around important sites in the hamlet, e.g., asyagi, hasagi or haisyo. The Hasagi, also called kami-asagi, is a small building in a sacred place, where guardian deities were summoned for the holding of ceremonies and rituals (Nakamatsu 1977). The Kami-asagi used to be a small building with a low thatched roof supported by four pillars without walls or a floor. At present, most of the kami-asagis have been rebuilt with concrete or tiled roofs.

Asagiya: is the local name for asagi in Bise village. Figure 3a shows Fukugi trees older than 200 years were clustered around houses surrounding the asagiya: The Asagiya: is at the center of Bise village, with the oldest houses around it. In the area in the north of the asagiya:, Fukugi trees were younger, generally not older than 150 years. The distribution of large Fukugi trees here suggests the houses surrounding the asagiya: are the core area of Bise, and that the village developed from its southern part to the northern part.

Hasaginkwa: and Fupuhasagi are two kami-asagis belonging to Imadomari and Oyatomari in Imadomari, respectively (HCCN 2007). It was found that houses around these two $\mathrm{ka}$ mi-asagis have more Fukugi trees in excess of 200-years-old than other areas. A broad road of about $250 \mathrm{~m}$ between the two kami-asagis is called baba (馬場), which was an open space used for horse training, horse racing, and tug-of-war. This place is now where the Harvest Festival is held every year.

In Tonaki Island, large Fukugi trees older than 200 years are clustered in the eastern part of the island, while Fukugi trees in the western part are younger (Figure 3b). Four haisyos out of a total of five inside the village are located in the eastern part. From Figure $3 b$, one will find the Fukugi trees older than 200 years were clustered in the eastern part of the village. It is obvious that houses in the current residential site were built in the eastern part in earlier years and later in the western part of the village.

Tomari Hara is thought to be the earliest settlement of Aguni village, where people moved from a mountainous area in the west to the current flat area (Aguni Son Shi 1984). It is difficult to pinpoint the exact location of Tomari Hara. Its boundary was drawn by a local villager named Tsuyoshi Komine. The Ufuya: (大屋) and ni:ya (根屋) are located in this area. Ufuya: is the male deity of the village and its habitat is a sacred place.

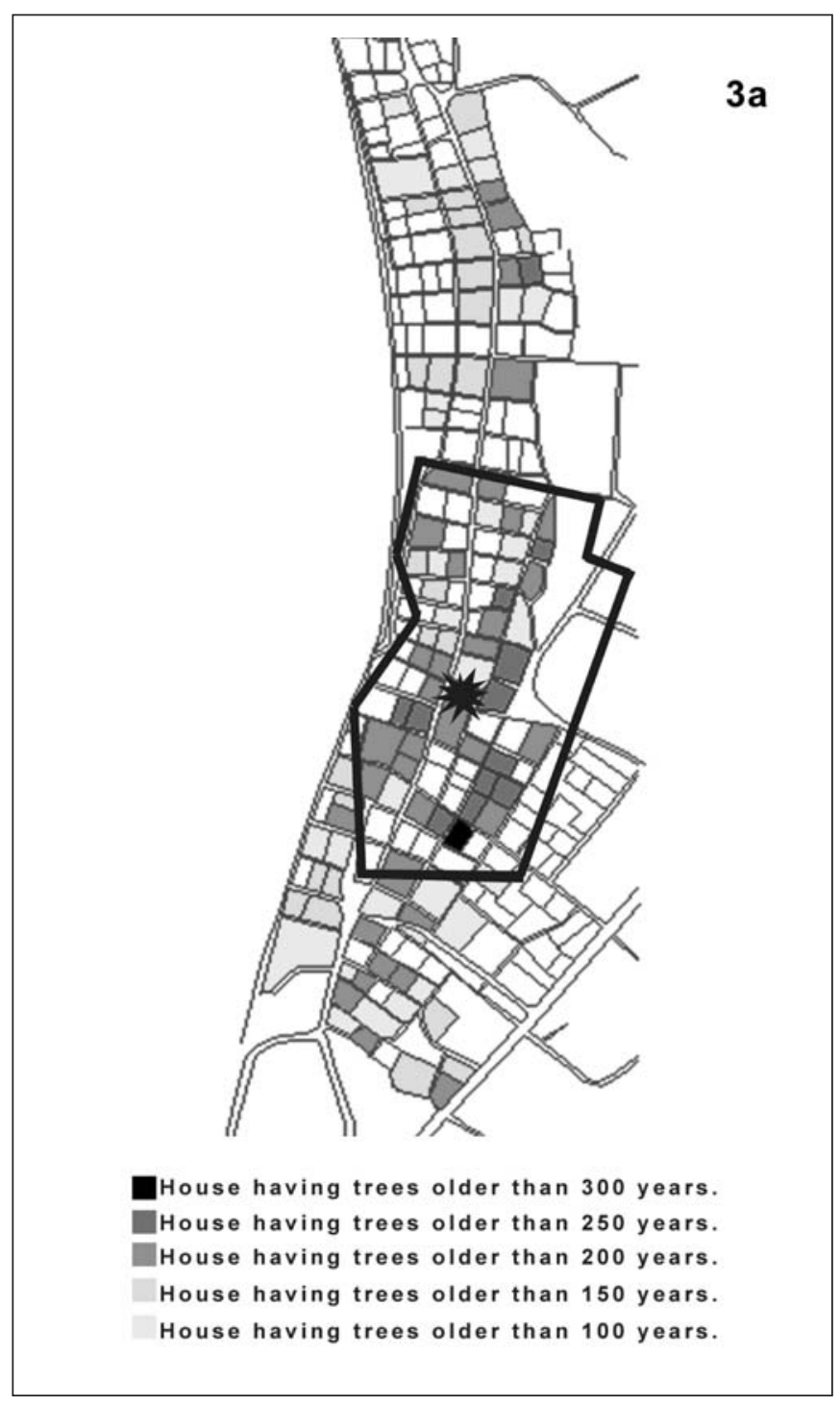

Figure 3. Distribution of old house-embracing Fukugi trees older than $\mathbf{1 0 0}$ years inside selected villages. The grayscale legend is pertinent to Figures 3a-3e. 3a) Bise village. The darkened star indicates the location of Kami-asagi.

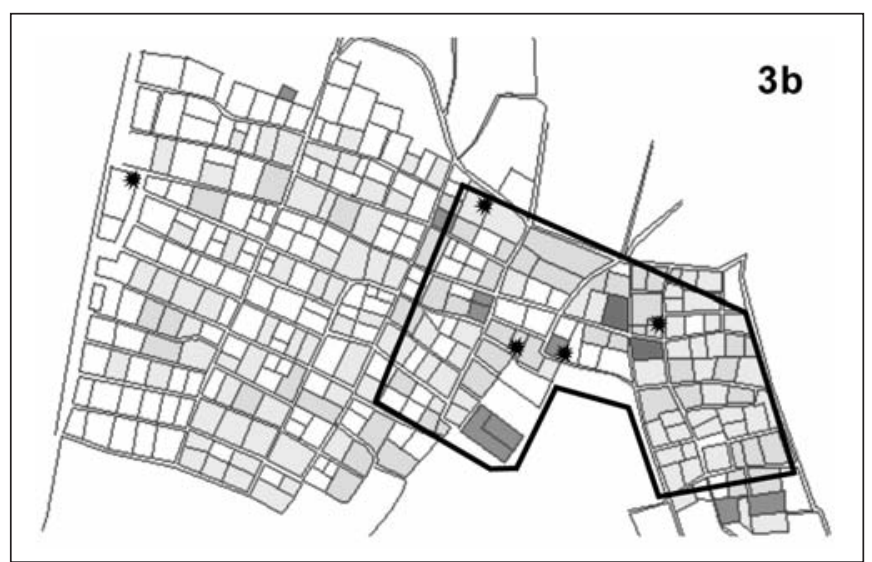

Figure $3 \mathrm{~b}$. Tonaki. The darkened stars indicate locations of haisyo, the place where individuals pray to the gods. 
In mainland Okinawa and its surrounding islands, the house of the earliest family that settled in a hamlet was called ni:ya, which became the center of hamlet rituals. Figure $3 \mathrm{~d}$ shows rees older than 200 years are clustered around Tomari Hara.

The biggest Fukugi trees were found to be around the old houses at the foot of the high land behind Hama hamlet, although the number of large Fukugi trees is much fewer than in other survey sites.

As mentioned earlier in this study, the oldest parts of the hamlets in the survey sites are also the location of most of the large Fukugi trees older than 200 years. Not exclusively, it must be said, since large trees can be found in places other than core areas. In particular in Imadomari and Yae in Aguni Island, large trees older than 200 years were found scattered here and there in the village. Fukugi trees around 300 years were also found in Bise (Figure 3a). The present village landscape, with large Fukugi trees older than 200 years and orderly road layout, might have been planned and built during the Sai On period from 1737 to 1750 . The age of some trees suggests that some houses might have moved to the current residential area with Fukugi trees planted as windbreaks to protect the houses before the Sai On period.

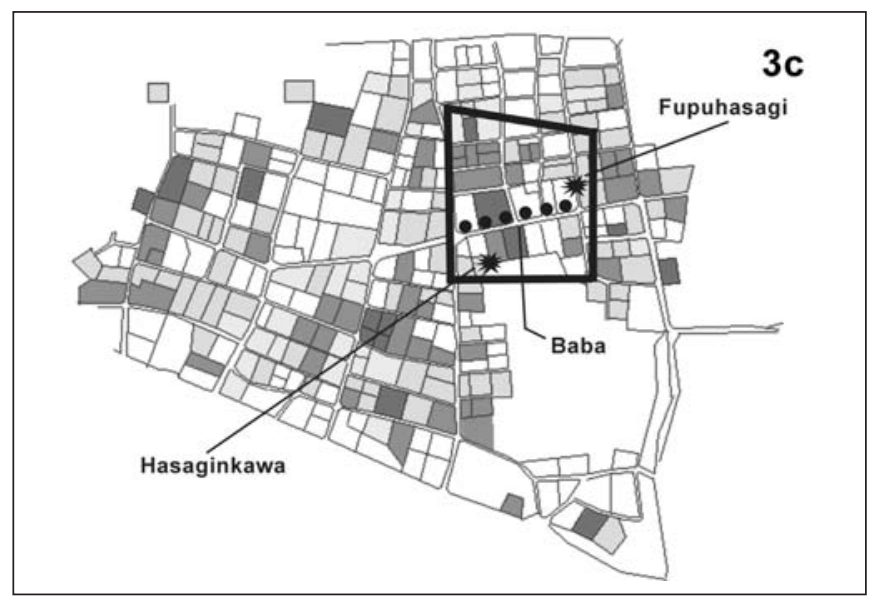

Figure 3c. Imadomari. The dotted path indicates the location of Baba. It was an open space used for horse training, horse racing, and playing tug-of-war. Now it is where the Harvest Festival is held every year.

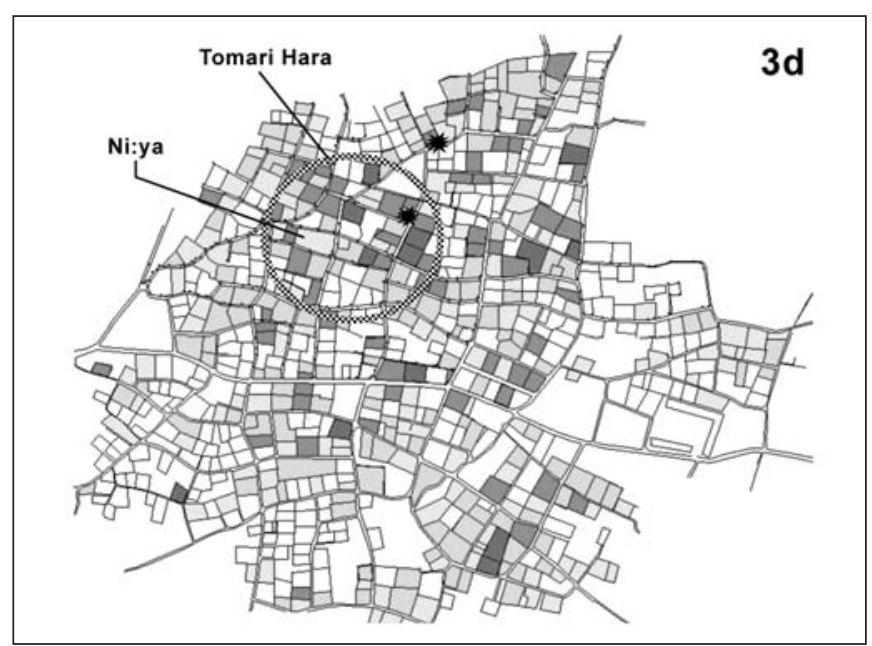

Figure 3d. Yae (East \& West). The area inside the patterned circle is Tomari Hara, which is supposed to be the location of the earliest habitation in the current village site (Aguni Son Shi 1984).

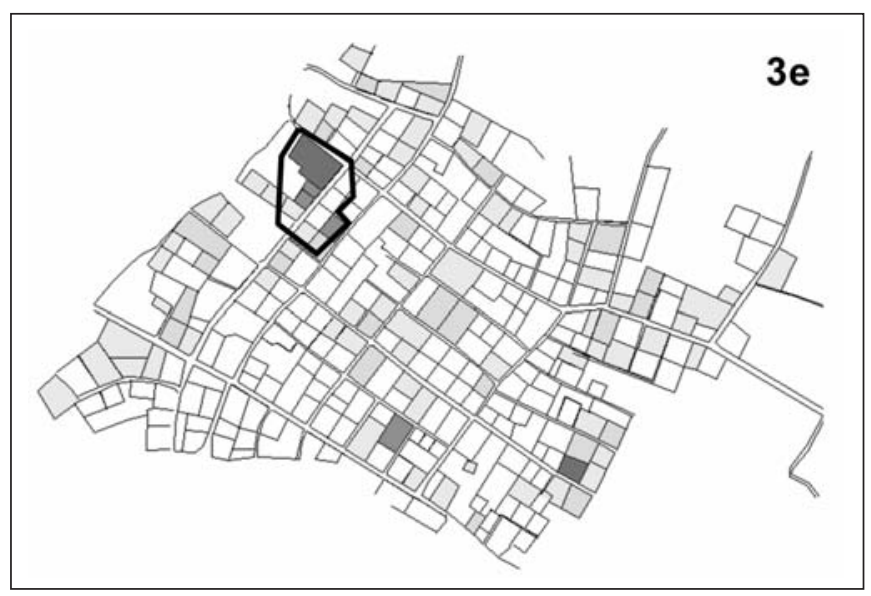

Figure 3e. Hama. The area inside the dark line is thought to have been the older parts of the hamlet.

\section{CONCLUSIONS}

A Feng Shui village landscape, assumed to have been planned or reformed during the modern Ryukyuan Period, features Fukugi house-embracing trees and an orderly road layout. Fukugi trees are well preserved on Okinawa Island and its nearby isolated islands. However, it is still a mystery to historians when and how these Fukugi trees were planted. In order to clarify the development process of the house-embracing Fukugi trees, all Fukugi trees that were assumed to be older than 100 years in Bise, Tonaki, Imadomari, and Aguni Island were measured. The surveyed hamlets were located on the fringe of Okinawa Island and its nearby smaller islands. Exposure to the sea might be one factor accounting for the preservation of Fukugi trees.

Fukugi trees older than 100 years were prevalent in all surveyed hamlets. Trees older than 200 years, however, were more common in Bise and Imadomari, and at Yae in Aguni Island than in Tonaki and Hama, Aguni Island. The spread of older trees in the former three villages was wider than in the latter two villages, suggesting the former three might have been settled at the current sites earlier than the latter two. The mean heights of large Fukugi trees were taller in Bise and Imadomari than in Tonaki and Aguni Island. A higher value placed on Fukugi trees by local people might be one important factor for having a better preservation of Fukugi trees.

The spatial distribution of old Fukugi trees in a Feng Shui village in Okinawa also suggests that strong wind has been the primary factor for such a layout. The oldest trees standing around the older part of the settlement were farther from the ocean than the younger trees.

Kami-asagi in northern Okinawa Island and haisyo on its nearby isolated islands were thought to be the hamlet center, with the houses around it forming the earliest settlement area. The present study found that large Fukugi trees older than 200 years are clustered in the core area around the kami-asagi or haisyo in the village. Fukugi trees in the northern part of Bise and the western part of Tonaki were younger than those in the core area near the kami-asagi, or haisyo. Thus, a traditional village in Okinawa was laid out with a structure related to the local religion and sacred rites at its center.

The oldest tree of around 300 years might have been planted prior to the period from 1737 to 1750 , when Sai On was a Sanshikan, during which Fukugi trees were planned and rec- 
ommended. Fukugi trees were planted as windbreaks around houses before the Sai On period, however, with the current house-embracing Fukugi tree landscape coming into being during the Sai On period and based on the Feng Shui concept.

Feng Shui village landscapes with numerous large Fukugi trees which were planned hundreds of years ago is a cultural landscape which should be reevaluated, preserved, and utilized as a green tourist resource in a contemporary context.

Acknowledgments. This paper is part of the research conducted for "A Basic Landscape Ecology Study on Traditional Village Landscape in East Asia Using GIS Software" funded by the Japan Society for the Promotion of Science (JSPS) for a postdoctoral fellowship. We would also thank Mr. Tsuyoshi Komine in Aguni Island and many other local people for their sincere cooperation during the field surveys and for providing local knowledge for this research. Thanks also go to Associate Editor, and Editor-in-Chief, Prof. Gary Watson of Arboriculture \& Urban Forestry and the three anonymous reviewers for their comments. We also wish to thank Dr. John Michael Purves for proofreading the manuscript.

\section{LITERATURE CITED}

Aguni Son Shi. 1984. Chronography of Aguni Village. Aguni Son Shi Editorial Board. (in Japanese)

Aguni Village Statistical Data. Retrieved November 17, 2009. <http:// www.vill.aguni.okinawa.jp/html/village/data.html>

Ando, T. and K. Ono. 2008. A study of physical characteristics of premises forest in Bise Village, Okinawa Island. Journal of Architecture and Planning 73(630):1729-1733.

Chandrakanth, M.G., M.G. Bhat, and M.S. Accavva. 2004. Socio-economic changes and sacred groves in South India: Protecting a communitybased resource management institution. Natural Resources Forum 28:102-111.

Chen, B., Y. Nakama, and G. Kurima. 2005. A study on a Feng Shui village and layout of habitat embracing trees in Okinawa (I). Journal of the Japanese Society of Coastal Forest 5(1):7-12.

Chen, B., Y. Nakama, and G. Kurima. 2006. A Study on village landscape and the layout of habitat-embracing Fukugi trees in Okinawa (II): A case study of Bise Village in Motobu Town, Okinawa. Journal of the Japanese Society of Coastal Forest 6(1):13-19.

Chen, B. 2008. A comparative study on Feng Shui village landscape and Fend Shui trees in East Asia: A case study of Ryukyu and Sakishima Islands. Science Bulletin Faculty of Agriculture University of Ryukyu 55:25-80.

Chen, B. and Y. Nakama. 2010. A study of the Village Forest Landscape in Small Island Topography in Okinawa, Japan. Urban Forestry \& Urban Greening, Issue 2 Volume 9. (Online article in press)

Chen, B. and Y. Nakama. 2011. A Feng Shui landscape and Feng Shui woods in an island village - a case study of Okinawa Prefecture, Japan. Worldviews: Global Religion, Culture, and Ecology, Vol. 15, No. 1. (accepted)

Chen, B., Y. Nakama, and G. Kurima. 2008a. A study on the Ryukyu Islands Feng Shui village landscape. Worldviews: Global Religion, Culture, and Ecology 12(1):25-50.

Chen, B., Y. Nakama, and G. Kurima. 2008b. Layout and composition of house-embracing trees in an island Feng Shui village in Okinawa, Japan, Urban Forestry \& Urban Greening 7(1):53-61.

Hirata, E. 2006. On the estimation of the age of an old Garcinia subelliptica tree. In: NPO Body Corporate of Yamabiko (Ed.). On the Garcinia Subelliptica Trees in Okinawa. Okinawa Green Promotion Committee, Naha. pp. 41-46. (in Japanese)
History and Culture Center of Nakijin Village (HCCN). 2007. Nakijin Kenkyuu (Research on Nakijin), Vol. 15.

Machida, M., and A. Tsuzuki. 1993. An introduction to Feng Shui village-studies on Hokubokusan Feng Shui Ki. Ryukyu University, Law Faculty Bulletin (History and Geography) 36, pp. 99-213 (in Japanese).

Mgumia, F.H., and G. Oba. 2003. Potential role of sacred groves in biodiversity conservation in Tanzania. Environmental Conservation 30:259-265.

Nakama, Y., and Z. Koki. 2002. The significance of housing shelter forest and regional inhabitants' consciousness in island regions. Journal of the Japanese Society of Coastal Forest 2(1):5-11.

Nakamatsu, Y. 1977. The ancient village: a folklorist study of Okinawa. Okinawa Times Press, Naka. (in Japanese)

Okinawa Greening Promotion Committee. 1999. Okinawa Furusato No Meiboku (Famous Trees in the Home Towns of Okinawa). (in Japanese)

Ono, M. 2006. Haneji Makija Inamine Fuusui Nikki (Feng Shui Diaries of Makija and Inamine). Municipal office of Nago, Okinawa. (in Japanese)

Purves, J., B. Chen, and Y. Nakama. 2009. The Secrets of Forestry: An English Translation of the Sanrin Shinpi (山林真秘) of Sai On. The Science Bulletin of the Faculty of Agriculture, No. 56:61-72.

Ramanujam, M.P., and K.P.K. Cyril. 2003. Woody species diversity of four sacred groves in the Pondicherry region of South India. Biodiversity and Conservation 12:289-299.

Shigematsu, T. 1979. Studies on the structural and visual character of house-shelterbelts on Iriomotejima Island, Okinawa. Bulletin University of Osaka Prefecture Series B 31, 1-13.

Upadhaya, K., H.N. Pandey, P.S. Law, and R.S. Tripathi. 2003. Tree diversity in sacred groves of the Jaintia hills in Meghalaya, northeast India. Biodiversity and Conservation 12, 583-597.

United States Civil Administration of the Ryukyu Islands. 1953. Ryukyu Islands: Forest Situation Specil Bulletin.

Zhuang X.Y., and R.T. Corlett. 1997. Forest and Forest Succession in Hong Kong, China. Journal of Tropical Ecology 13:857-866.

Bixia Chen (corresponding author)

School of Economics

Fujian Normal University

JSPS Postdoctoral Fellow

Faculty of Agriculture

University of the Ryukyus

Senbaru, Nishihara Town

Nakagami Gun, Okinawa 903-0213

Japan

bixia.chen@gmail.com

Yuei Nakama

Professor

Department of Subtropical Agricultural Science

Faculty of Agriculture

University of the Ryukyus 
Résumé. L'aménagement paysager d'un village Feng Shui implique l'emploi d'alignement d'arbres composés de Fukugi (Garcinia subelliptica) qui entourent chacune des maisons ainsi que de part et d'autres de routes organisées de manière relaxante. Ce type d'aménagement paysager végétal, qui a été conçu ou organisé durant la période moderne du Ryukyuan il y a environ 300 ans, a été très bien conservé sur l'île d'Okinawa au Japon ainsi que sur les autres îles isolées à proximité. Le mystère demeure cependant toujours pour les historiens à propos de savoir quand et comment ces Fukugis ont été plantés. Afin de clarifier le processus de développement des Fukugis entourant les maisons, tous les Fukugis dont on assumait qu'ils étaient âgés de plus de 100 ans ont été mesurés sur les îles de Bise, Tonaki, Imadomari et Aguni. On a découvert que les immenses Fukugis de plus de 200 ans se regroupaient autour de la place centrale du kami-asagi ou haisyo à l'intérieur du village. Le kami-asagi et le haisyo sont des places sacrées où les dieux gardiens sont appelés lors de la tenue des cérémonies et des rituels. Les plus vieux arbres ont approximativement 300, 268, 294, 296 et 281 ans respectivement à Bise, Tonaki, Imadomari, Yae (Est et Ouest) et Hama dans l'île Aguni. Ces vieux arbres pourraient avoir été plantés antérieurement à la période comprise entre 1737 et 1750 lorsque Sai On était un membre du Sanshikan au cours de laquelle l'emploi des Fukugis était recommandé. Alors que les fukugis pourraient avoir été plantés en tant que brise-vent autour des maisons avant la période du Sai On, l'aménagement paysager actuel avec des fukugis entourant les maisons est devenu réalité durant la période du Sai On en se basant sur les concepts du feng shui.

Zusammenfassung. Eine Feng shui Dorflandschaft ist gekennzeichnet durch Fukugi-Baumreihen, die jedes Haus umgeben und die ordentlichen Straßen säumen. Solche Landschaften, welche vermutlich in der neuen Ryukyuan Periode vor ca. 300 Jahren geplant oder reformiert wurden, sind auf der Insel Okinawa und den benachbarten Inseln gut erhalten. Aber es ist für die Historiker immer noch ein Geheimnis, wann und wie diese Fuguki-Bäume gepflanzt wurden. Um den Entwicklungsprozess dieser hausumgebenden Fukugi-Bäume zu klären, wurden alle Bäume auf den Inseln Bise, Tonaki, Imadomari und Aguni, die wesentlich alter als 100 Jahre sind, gemessen. Es wurde festgestellt, daß sich große Fukugi
-Bäume, die alter als 200 Jahre waren, um das Zentrum kami-asagi oder haisyo im Dorf gruppieren. Sowohl kami-asagi und haisyo sind heilige Pläte, wo Schutzgötter versammelt sind und Zeremonien und Rituale abgehalten werden. Die ältesten Bäume waren schätzungsweise 300, 294, 296 und 281 Jahre alt und standen auf Bise, Tonaki, Imadomari Yae (Ost und West) und Hama auf der Insel Aguni. Diese alten Bäume könnten vor der Periode von 1737 - 1750 gepflanzt worden sein, als Sai On ein Mitglied der Sanshikan war, während der Fukugi-Bäume gepflanzt und empfohlen wurden. Während die Fukugi-Bäume vor der Sai On Periode möglicherweise als Windschutz um die Häuser gepflanzt wurden, sind die gegenwärtigen hausumgebenden Fukugi-Baumlandschaften in der Sai On Periode auf der Basis von Feng shui Konzepten angelegt worden.

Resumen. Un paisaje Feng Shui caracteriza las líneas de árboles Fukugi (Garcinia subelliptica) alrededor de cada casa y metódicamente fuera de las carreteras. Como tal un paisaje verde, planeado y reformado durante el período moderno Ryukyuan alrededor de 300 años, está bien preservado en Okinawa Island, Japón, y sus islas vecinas aisladas. Pero es aún un misterio para los historiadores cuándo y cómo estos árboles Fukugi fueron plantados. Con el fin de clarificar el proceso de desarrollo de las casas asociadas a estos árboles, todos fueron asumidos en 100 años de edad en las islas Bise, Tonaki, Imadomari, y Aecguni. Se encontró que los árboles más viejos fueron de 200 años, agrupados alrededor del área núcleo kami-asagi o haisyo dentro de la villa. Los dos lugares, kami-asagi y haisyo, son espacios sagrados donde los dioses guardianes fueron convocados en ceremonias y rituales. Los árboles más viejos son aproximadamente de 300, 268, 294, 296 y 281 años en Bise, Tonaki, Imadomari, Yae (East \& West), y Hama en Aguni Island, respectivamente. Estos viejos árboles pudieron haber sido plantados antes del período de 1737 a 1750, cuando Sai On era miembro del Sanshikan, durante el cual los árboles Fukugi fueron planeados y recomendados. Mientras que los árboles Fukugi pudieron haber sido plantados como rompevientos alrededor de las casas antes del período Sai On, sin embargo, las casas en la actualidad se cree que los árboles vienen siendo durante el período Sai On con base en los conceptos Feng Shui. 